\title{
"An introduction to the prospect of the Chinese RMB as a reserve currency"
}

\begin{tabular}{|c|c|c|}
\hline AUTHORS & Paul Gentle & \\
\hline ARTICLE INFO & $\begin{array}{l}\text { Paul Gentle (2016). An introduct } \\
\text { reserve currency. Banks and } B a \\
\text { doi:10.21511/bbs.11(1).2016.08 }\end{array}$ & $\begin{array}{l}\text { of the Chinese RMB as a } \\
71-76 .\end{array}$ \\
\hline DOI & http://dx.doi.org/10.21511/bbs.11 & \\
\hline RELEASED ON & Monday, 25 April 2016 & \\
\hline JOURNAL & "Banks and Bank Systems" & \\
\hline FOUNDER & LLC “Consulting Publishing Con & erspectives" \\
\hline & & $\begin{array}{l}\text { ニ- } \\
\text { =E }\end{array}$ \\
\hline NUMBER OF REFERENCES & NUMBER OF FIGURES & NUMBER OF TABLES \\
\hline 0 & 0 & 0 \\
\hline
\end{tabular}

(c) The author(s) 2023. This publication is an open access article. 
Paul F. Gentle (China)

\title{
An introduction to the prospect of the Chinese $\mathrm{RMB}$ as a reserve currency
}

\begin{abstract}
On October 1, 2016, the Chinese RMB (yuan) will be included in the SDRs of the International Monetary Fund (IMF). Reserve currencies are select currencies that have special drawing rights (SDRs). This article examines some of the aspects of this impending change of including the Chinese RMB as a select currency. The U.S. dollar is expected to continue to dominate as a select currency, after October 1, 2016, for the foreseeable future. This article has been written so as to provide general economists with some understanding of special drawing rights (SDR) of the International Monetary Fund (IMF) and how the addition of the Chinese RMB will fit in, as of October 1, 2016.
\end{abstract}

Keywords: special drawing rights of International Monetary Fund, Chinese RMB, Chinese yuan. JEL Classification: E10.

\section{Introduction}

In 2015, the International Monetary Fund (IMF) approved the October 1, 2016 inclusion of the Chinese RMB in the SDRs (special drawing rights). This will make the Chinese RMB a reserve currency. The next four Sections present a literature review. The Final Section gives a summary and conclusion.

\section{First British currency and then American currency}

In 1899, the share of the British Pound in known foreign exchange holdings of official institutions had been large. The British Pound also had a much greater share of known foreign exchange holdings than the American dollar. At that time, the holdings were in American dollar value terms: \$105.1 million in British Pounds; \$ 27.2 million in French Francs; \$24.2 million in German Marks; \$9.4 million in other currencies (Chinn and Frankel, 2008). In 1913, on the eve of World War I, which started in 1914, the situation had not changed much. The British Pound constituted \$425.4 million; \$275.1 million in French Francs; \$136.9 million in German Marks was \$55.3 in other currencies. Even in 1940, the British Pound had the highest amount of known foreign exchange (Lindert, 1969, pp. 16-22; Chinn and Frankel, 2008).

World War II included the U.S. lending money to the U.K., which in itself was one factor in the ascent of the U.S. dollar. The British Pound lost its preeminence, as the U.K. lost some of her economic preeminence, some of her colonies, some of her relative military power, and some of her other traits of her ability to greatly influence other nations (Chinn and Frankel, 2008).

By 1945, the Dollar was the currency of most importance for known foreign exchange (Aieber, 1966, pp. 19-20; Chinn and Frankel, 2008). After World

(C) Paul F. Gentle, 2016.

Paul F. Gentle, Assistant Professor, NCC British Higher Education Guangzhou Institute of Technology, Guangzhou, China.
War 2, the Bretton Woods system of fixed exchange rates, in regard to the U.S. dollar,was implemented. Although the fixed exchange rate lasted only from 1945 to 1971, there is still the use of USA dollars for reserve currency. In this way, the U.S. dollar is used by other countries to denominate the assets that they hold as international reserves (Mishkin, 2006). However, there are now other reserve currencies designated by the International Monetary Fund (IMF). The tendency of the United States to mount up total budget debt, the use of inflation for debt monetization and the budget pressures from many military miscalculations in the Middle East could affect the U.S. dollar as a reserve currency in the years to come (Chinn and Frankel, 2008).

Any change in one currency as being the main foreign exchange currency to a different currency having that role is a gradual change. We can see that in the example of the British Pound giving way to the American Dollar as the main foreign exchange currency. In reality, there is some "inertia" that slows that change of any country's currency being the main currency into another country's currency being the main one (Chinn and Frankel, 2008).

\section{Chinese $\mathrm{RMB}$}

The Chinese RMB (remninbi), means "the people's currency" in Mandarin. On October 1, 2016, it will join the ranks of those currencies that are designated reserve currencies. SDR's, special drawing rights, refer to a basket of currencies used by the Washington based International Monetary Fund (IMF) as its unit of account (Economist, 2015). IMF Managing Director Christine Lagarde stated that the inclusion of the RMB in SDR's indicates that reforms in international trade have been implemented (Bloomberg, 2015a). SDR (special drawing rights) are not, technically, a currency. However, IMF member countries have the right to obtain any of the currencies in the basket of designated SDR currencies (Mayeda, 2015a). Investors correctly choosing a currency may achieve an increase in liquidity. This may avert some risk 
(Feldstein, 1999). SDR, currently composed of weighted rates of the British Pound, the U.S. dollar, the Euro, and the Japanese Yen must have the addition of the Chinese RMB, so that IMF member countries can convert SDRs into Chinese RMB easily. When the Chinese RMB becomes part of the SDR, central bank reserve managers and financial institutional investors will accumulate more RMBdenominated assets (Chen, 2015; Mayeda, 2015a).

The inclusion of the RMB in the SDR will only deepen the expectations that China will let market forces decide the Yuan's exchange rate (a Yuan is the primary unit of account of the renminbi (Chinese Yuan, 2016)). It is well known that China has a preference for gradual reform (Economist, 2015). In gaining inclusion in the SDRs for the Chinese RMB, the Chinese "must be aware of the responsibility to minimize intervention" by the Chinese government (Economist, 2015). In agreement, Rao (2015) points out that after it was announced that the Chinese RMB, the People's Bank of China (China's central bank) would allow the RMB currency to be governed more by market forces. After initial beginning adjustments, the increasing internationalization of the RMB will increase its spread across central banks of countries outside China (Mayada 2015a, 2015b; Rao, 2015).

A relatively lower Chinese RMB does benefit Chinese exporters (Panda, 2015). It will be interesting to see how making the Chinese RMB a reserve currency affects this in the immediate run and long run. Chin and Wang (2010) state that Chinese policy makers support a multi-currency reserve system, with greater use of SDRs and the "internationalization of the renminbi". Rao (2015) states that the increased demand for Chinese RMB will have some effect in causing the RMB to appreciate. To what extent that will happen, remains to see.

John Zhu of the HSBC (Hang Seng Banking Corporation) states that internationalization of the RMB and the policy for opening up China's capital account is the Chinese government's stated policy (Zhu, 2015). Both the emergence of the Asian economy and the greater use of the Chinese RMB have been two of the most notable features of the new economy (Lee, 2013). At this time, the U.S. Dollar dominates as the currency for international trade. A high degree of RMB internationalization requires significant capital account liberalization (Eichengreen et al., 2014). The capital account refers to the net receipts from capital transactions (Mishkin, 2006). However, Lee (2014) argues for the inclusion of the Chinese RMB as a reserve currency to facilitate trade. Although, Zhu (2014) states that it will take time for the RMB to be consi- dered as a meaningful amount of global foreign exchange reserve. Chen (2015) states that SDR inclusion for the Chinese RMB is a "win-win" situation for both China and other countries, according to the People's Bank of China. There are some reasons why central banks are starting to do so now. The most obvious reason is to facilitate trade. The removal of the requirement for both sides to make a conversion into a third currency is logical (Zhu, 2014). "Invoicing in the RMB also improves pricing transparency for customers and reduces currency risk for trading partners" (Zhu, 2014).

\section{Chinese $R M B$ internationalization}

With the advent of 2016, it will be profitable for observers of Asia to continue to watch the renminbi closely. The Chinese RMB will continue to be instructive of more than just the health of the Chinese economy. The renminbi's entry into uncharted waters is on October 1, 2016, when it will become a reserve currency and an increasingly internationalized currency (Panda, 2015). Acceptance of the Chinese RMB as a reserve currency will encourage further economic reform in China (Bloomberg, 2015a). The Chinese RMB's having been considered and actually selected as a reserve currency by the International Monetary Fund, results in more countries being comfortable in using RMB and including it in their foreign-exchange holdings (Bloomberg, 2015b). According to Standard Chartered Plc and AXA Investment Managers, at least $\$ 1$ trillion of global reserves will convert to Chinese assets if the Yuan joins the IMF's reserve basket, (Bloomberg, 2015b). According to one source, there are four reasons why the Chinese RMB is not expected to anytime soon, overtake the U.S. Dollar as the most important reserve currency:

- The Yuan is tightly controlled by the Chinese government, even with requests by Western nations to loosen control more.

- The RMB (Yuan) is used internationally in a limited way.

- The rising middle class in China demands more certainty from the government.

- Historically, the dominant country in a national defense sense, has a great influence in the reserve currency scheme. For the foreseeable future, that dominate country will be the United States (Finances, 2015).

Harjani (2014) provides a poll of how institutional investors see things between the Chinese RMB (Yuan) and the U.S. dollar. There are two groups in the sample of the 200 people surveyed in this poll. One group is composed of 100 institutional investors inside the Chinese mainland. The other 100 is composed of institutional investors outside the Chi- 
nese mainland, with the names supplied by The Economist magazine. Not surprisingly, within Mainland China, "optimism was higher" for the Chinese RMB Yuan to supersede the U.S. dollar. Indeed, 62 percent of those who are on the Chinese Mainland, view the RMB as being able to supersede the U.S. dollar as a reserve currency; whereas, those polled outside Mainland China yielded only 43 percent agreeing that the Chinese RMB would supersede the U.S. dollar as a reserve currency.

The U.S. dollar has been an important world standard, especially for international trade. Unfortunately, due to strategies to soften the effects of the Great Recession, the increases in the money supply for the U.S. dollar have been very great in recent years (Gentle and Jones, 2015). Possibly, this could be an adverse factor in terms of how good a store of value the U.S. dollar is. There has been a great expansionary policy by the FED; thus, "China has been provoked into speeding RMB "internationalization", due to concerns about the long-term ability of the U.S. dollar to act as a store of value (McKinnon and Schnabi, 2014). This RMB internationalization opens up Chinese "domestic financial markets to reduce its dependence on the U.S. dollar for invoicing trade and making international payments" (McKinnon and Schnabi, 2014) There are complications in doing this internationalization. Issues concerning Chinese authorities have to be concerned about interest rates and inflows of foreign capital, for example (McKinnon and Schnabi, 2014). Although Cohen and Benney (2014) acknowledge the changes in the international currency system, they state that aside from any other considerations, the level of competition has to be taken into account also. The competitive structure of the international currency system has changed slowly over the last two decades (Cohen and Benney, 2014). Eichengreen et al. (2014) find that "much progress has been made on RMB settlements for trade involving the People's Republic of China (PRC) and on RMB-denominated bond issuance in Hong Kong" (Eichengreen et al., 2014). Shu and Cheng (2015) maintain that there is "growing influence of the Chinese RMB in the Asia-Pacific region".

These changes, in turn, would call for greater exchange rate flexibility so that the People's Bank of China (the central bank) can enjoy monetary policy autonomy. Exposure to any volatility in fi- nancial markets will also have to be taken into account (Eichengreen et al., 2014). According to Durden (2015), the inclusion of the Chinese RMB as an International Monetary Fund (IMF) reserve currency puts pressure on Beijing in regard to how it manages the Yuan, and how the Chinese government communicates with investors and the world. China has pledges "to loosen its tight grip on the currency's value" and the openness of China's financial system will come under new scrutiny (Durden, 2015). Importantly, the "history of the Japanese internalization offers a cautionary tale" (Durden, 2015). The Japanese example suggests that (a) a floating exchange rate, (b) free cross-border flows and (c) stable economic growth are all necessary for any internationalization that is successful (Durden, 2015).

The International Monetary Fund's press releases on the inclusion of the Chinese in currencies with SDRs included the expectation that China would continue its financial and monetary reforms. It is thought that the Chinese RMB will "take on a more global role" (Rao, 2015).

\section{Examples of four illustrations and interpre- tations}

This Section of the article provides four illustrations that may help the reader to understand these concepts better. The concepts described in the four illustrations are: special drawing rights, current SDR currencies composition, strong Yuan effect on Chinese exports, and China becoming the largest economy, based on purchasing power parity (PPP). These diagrams and the explanations below them help to understand key aspects, concerning the Chinese RMB and its elevation in status to an International Monetary Fund (IMF) reserve currency.

Figure 1 (see below) describes special drawing rights. This phenomena refers to those select currencies that are included in the International Monetary Fund's basket of currencies known as "reserve currencies" (Economist, 2015). As of October 1, 2016, U.S. Dollars, Euros, Chinese Yuan, Japanese Yen and British Pound are the five currencies included. A weighted average of those currencies are used to make up the value of special drawing rights. As the diagram above illustrates, the value per currency is: U.S. dollar $41.73 \%$; Euro 30.93 $\%$, Chinese Yuan 10.92\%; Japanese Yen $8.33 \%$ and $8.09 \%$ for the British Pound (International Monetary Fund, 2015a; Mayeda, 2015b). 


\section{What are Special Drawing Rights?}

IMF member countries can borrow money at favourable rates from the IMF's reserves in any of the currencies listed in the SDR basket. These include the US dollar, the euro, Japan's yen, and the British pound. The fund also issues its crisis loans - crucial for struggling economies like Greece - valued in SDRs. SDR inclusion of the yuan is expected to help China open up further to the global economy. The yuan's entry into the SDR basket takes effect on October 1, 2016.

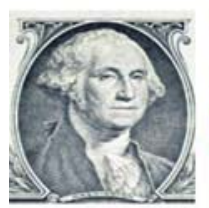

USD

41.73 per cent

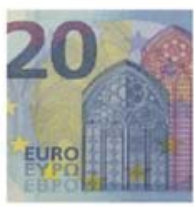

Euro

30.93 per cent

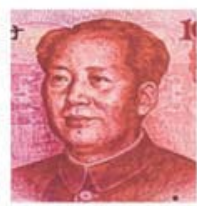

Chinese yuan

10.92 per cent

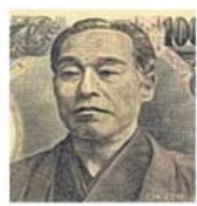

Japanese yen

8.33 per cent

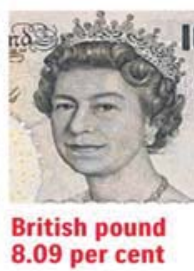

The value of the SDR is based on a weighted average of the currencies in the basket. With the inclusion of the yuan, the dollar's weight in the new basket will be at 41.73 per cent. The euro will be 30.93 per cent, the yuan 10.92 per cent, the yen 8.33 per cent, and the pound 8.09 per cent.

Fig. 1. Special drawing rights

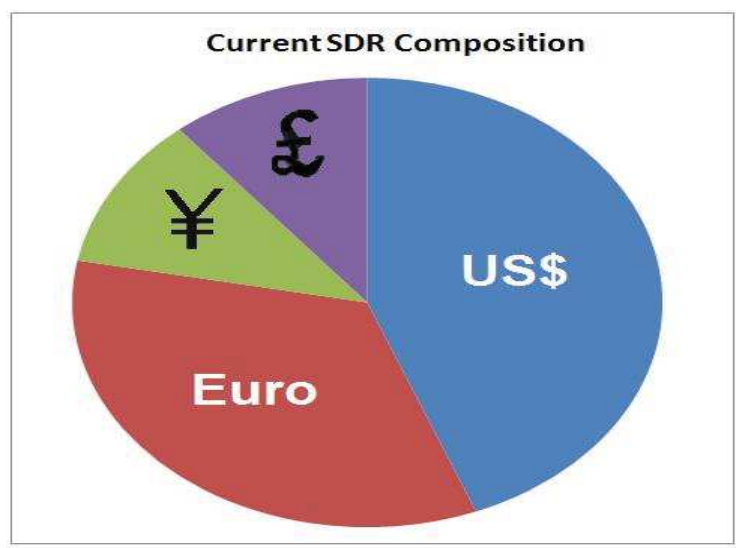

Fig. 2. Current SDR Composition

In Figure 2, note that on January 1, 1999 the Euro came into being. Therefore, the Deutsch Mark and the French Franc were phased out. The British Pound Sterling (11.3\%), the Japanese Yen (9.4\%), the U.S. dollar (41.9\%) and the Euro (37.4\%) are what remained. This chart is of a time period before the Chinese RMB becomes a reserve currency on October 1, 2016 (International Monetary Fund, 2015b; Reserve Currency, 2015).

In Figure 3, the real effective exchange rate is the weighted average of a country's currency relative to an index or basket of other major currencies adjusted for the effects of inflation (Investopedia, 2016). The higher the real effective exchange rate of Chinese RMB (Yuan) relative to that of other trading partners, then the less competitive are Chinese exports, relative to trading partners (Chan, 2015).

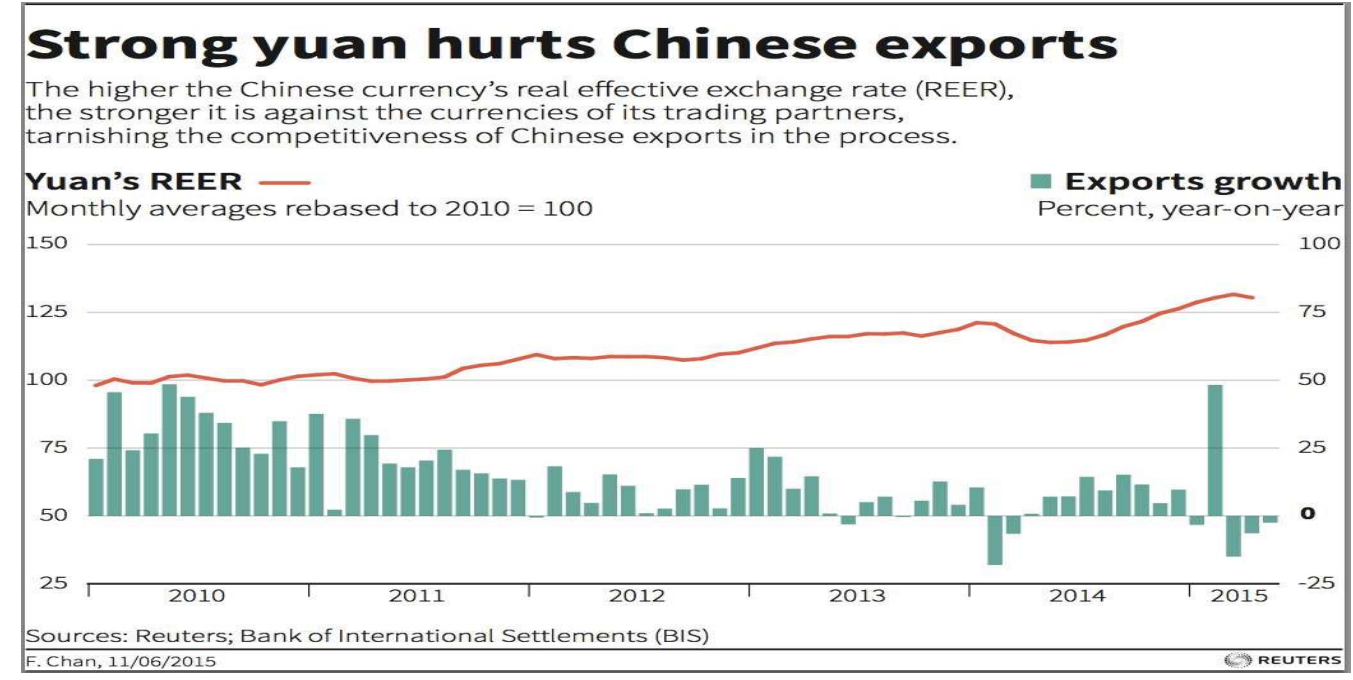

Fig. 3. A strong yuan hurts chinese exports 


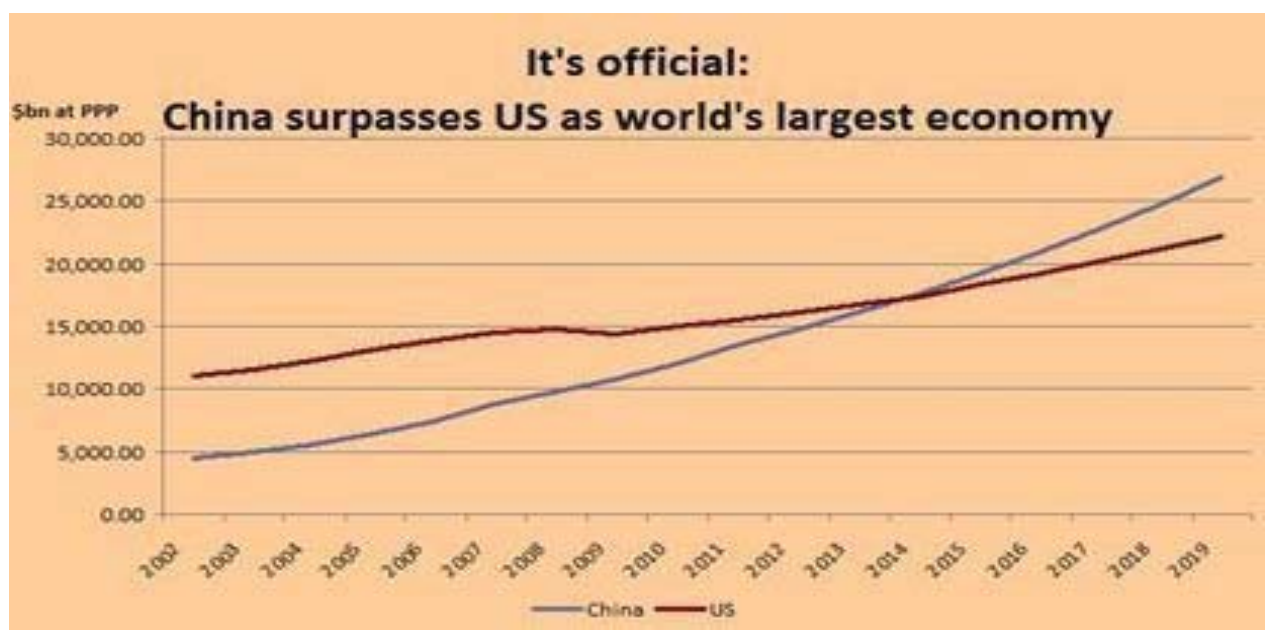

Fig. 4. China becomes world's largest economy

In Figure 4, possibly, in the year 2014, in terms of purchasing power parity, China surpassed the United States as the world's largest economy. (China surpasses U.S., 2015). However, in per capita terms, China lags far behind the United States (International Monetary Fund, 2015c).

\section{Summary and conclusion}

On October 1 of this year, 2016, the Chinese RMB will get special drawing rights and become a reserve currency of the International Monetary Fund (IMF). The Chinese government has promised to continue economic and financial reforms. A demonstrated good effort to pursue these reforms will increase the success of the Chinese RMB being used widespread in more international transactions. Along with the Chinese RMB, the U.S. Dollar, the Euro, the Japanese Yen and the British Pound will continue to have special drawing rights. A weighted average of those currencies is used to make up the value of special drawing rights. As of October 1, 2016, the value per currency will be: U.S. dollar 41.73\%; Euro 30.93\%, Chinese Yuan 10.92\%; Japanese Yen 8.33\%, and $8.09 \%$ for the British Pound. International trade will benefit from the inclusion of the Chinese RMB (Yuan) in the basket of currencies with special drawing rights (SDRs).

\section{References}

1. Aiber, Robert. (1966). The Future of the Dollar as an International Currency. New York: Praeger.

2. Bloomberg Business. (2015a). Why China Wants Yuan to be the World's 5th Reserve Currency. Available at: http://www.bloomberg.com/news/articles/2015-03-23/why-china-wants-its-yuan-to-be-the-world-s-5th-reservecurrency. Accessed: March 23.

3. Bloomberg Business. (2015b). IMF Said to Give China Strong Signs of Reserve Currency Nod, October 23. Available at: $\quad$ http://www.bloomberg.com/news/articles/2015-10-23/imf-said-to-give-china-strong-signs-of-reserve-currencyblessing.

4. Chan, F. (2015). Strong Yuan Hurts Chinese Exports, Reuters, November 6.

5. Chen, Sharon. (2015). Asian Central Banks Welcome Yuan's IMF Reserve - Basket Inclusion, Bloomberg Business, December 1.

6. Chin, G. and Y. Wang. (2010). Debating the International Currency System, What is in a Speech? China Security, 6 (1), pp. 3-20.

7. China Surpasses U.S. (2015). It's Official: China Surpasses U.S. as World's largest economy. Available at: https://socioecohistory.files.wordpress.com/2014/10/china_surpasses_us_as_worlds_largest_economy.jpg?w=460 $\& \mathrm{~h}=270$.

8. Chinese Yuan. (2016). Chinese Yuan. Available at: https://en.wikipedia.org/wiki/Chinese_yuan April 5.

9. Chinn, M. and J.A. Frankel (2008). Commentary: Why the Euro will Rival the Dollar, International Finance, 11 (1), pp. 49-73.

10. Cohen, Benjamin J. and Tabitha M. Benney. (2014).What does the international currency system really look like? Review of International Political Economy, 21 (5), pp. 1017-1041.

11. Durden, Tyler. (2015). The IMF Confirms Yuan Inclusion In SDR Basket At 10.92\% Weight, Above JPY And GBP, Zero Hedge, November, 30.

12. Economist. (2015).The Yuan Joins the SDR: Maiden Voyage Reserve-Currency Status Makes for a Weak Yuan, The Economist, December 5, 2015.

13. Eichengreen, Barry and Masahiro Kawei. (2014). Issues for Renminbi Internationalization: An Overview, Working Paper 454 Asian Development Bank Institute, pp. 1-20.

14. Feldstein, Martin. (1999). Self-Protection for Emerging Market Economies, National Bureau of Economic Research Working Paper Number 6907, January, pp. 1-25. 
15. Finances. (2015). 4 Reasons Why Yuan Won’t Replace Dollar as Reserve Currency, Finances. Online. Available at: http://financesonline.com/4-reasons-why-yuan-wont-replace-dollar-as-reserve-currency/.

16. Gentle, Paul. F. and Joseph Jones. (2015). Reflections concerning the Money Supply, Velocity, and the Quantity Theory of Money: the Great Depression and the Great Recession, in the United States, Banks and Bank Systems, 10 (2), June, pp. 71-82.

17. Harjani, Ansuya. (2014). Yuan to supersede dollar as top reserve currency: Survey, CNBC, February 26. Available at: http://www.cnbc.com/2014/02/26/yuan-to-supersede-dollar-as-top-reserve-currency-survey.html.

18. International Monetary Fund. (2015a). What are Special Drawing Rights? January 2. Available at: http://www.straitstimes.com/sites/default/files/st_20151202_yuan02_1882309.jpg.

19. International Monetary Fund. (2015b). List of Countries by GDP (PPP) Capita Income. Available at: https://en.wikipedia.org/wiki/List_of_countries_by_GDP_(PPP)_per_capita.

20. International Monetary Fund. (2015c). Special Drawing Right (SDR). International Monetary Fund, November 30, 2015. Available at: http://www.imf.org/external/np/exr/facts/sdr.htm.

21. Investopedia. (2016). Real Effective Exchange Rate. Available at: http://www.investopedia.com/terms/r/reer.asp. Accessed: January 2, 2016.

22. Lee, Jong Wha. (2013). Will the Renminbi Emerge as an International Reserve Currency? The World Economy, pp. 42 62, June 24, 2014.

23. Lindert, Peter. (1969). Key Currencies and Gold: 1900-1913, Princeton Studies in International Finance, Number 24, August.

24. Mayeda, Andrew. (2015a). What Will it Mean if the Yuan Gets Reserve-Currency Status, Bloomberg Business, October 23. Available at: http://www.bloomberg.com/news/articles/2015-10-24/what-will-it-mean-for-the-yuan-to-get-imfreserve-currency-nod.

25. Mayeda, Andrew. (2015b). IMF Approves Reserve Currency Status for China's Yuan, Bloomberg Business, November 30. Available at: http://www.bloomberg.com/news/articles/2015-11-30/imf-backs-yuan-in-reserve-currency-club-afterrejection-in-2010.

26. McKinnon, Ronald and Schnabi, Gunther. (2014). China's Exchange Rate and Financial Repression: The Conflicted Emergence of the RMB as an International Currency, China \& World Economy, 22, 3, July/August, pp. 1-35.

27. Mishkin, Frederic S. (2006). The Economics of Money, Banking and Financial Markets. New York: Pearson Addison Wesley.

28. Panda, Ankit. (2015). Uncharted Waters for the Renminbi in 2016: Moves by China's central bank and the IMF have seen the renminbi enter a new era, The Diplomat, December 22.

29. Rao, Nandiri. (2015). Impacts of the Yuan's Inclusion in the SDR currency basket, Global Insights: Know Your World, December 15. Available at: http://globalriskinsights.com/2015/12/impacts-of-the-yuans-inclusion-in-the-sdr-currencybasket.

30. Reserve Currencies. (2015). Available at: http://en.wikipedia.org/wiki/Reserve_Currency. Accessed: December 25.

31. Shu, C, D. He and Cheng X. (2015). One Currency, two markets: the Renminbi's Growing Influence in Asia-Pacific, China Economic Review, 33, April, pp. 163-178.

32. World Bank (2015). Per Capita GDP. Available at: http://data.worldbank.org/indicator/NY.GDP.PCAP.CD.

33. Zhu, John. (2014). Remninbi as a Reserve Currency, Central Banking Journal. Available at: http://www.centralbanking.com/central-banking-journal/advertisement/2357296/renminbi-as-a-reserve-currency. 